University of Nebraska - Lincoln

DigitalCommons@University of Nebraska - Lincoln

Faculty Publications from Nebraska Center for

Materials and Nanoscience, Nebraska Center Materials and Nanoscience

for (NCMN)

$12-24-2001$

\title{
Boron carbide/n-silicon carbide heterojunction diodes
}

Shireen Adenwalla

University of Nebraska-Lincoln, sadenwalla1@unl.edu

P. Welsch

University of Nebraska - Lincoln

A. Harken

University of Nebraska - Lincoln

Jennifer I. Brand

University of Nebraska-Lincoln, jbrand1@unl.edu

A. Sezer

University of Nebraska - Lincoln

See next page for additional authors

Follow this and additional works at: https://digitalcommons.unl.edu/cmrafacpub

Part of the Nanoscience and Nanotechnology Commons

Adenwalla, Shireen; Welsch, P.; Harken, A.; Brand, Jennifer I.; Sezer, A.; and Robertson, Brian W., "Boron carbide/ $n$-silicon carbide heterojunction diodes" (2001). Faculty Publications from Nebraska Center for Materials and Nanoscience. 85.

https://digitalcommons.unl.edu/cmrafacpub/85

This Article is brought to you for free and open access by the Materials and Nanoscience, Nebraska Center for (NCMN) at DigitalCommons@University of Nebraska - Lincoln. It has been accepted for inclusion in Faculty Publications from Nebraska Center for Materials and Nanoscience by an authorized administrator of DigitalCommons@University of Nebraska - Lincoln. 


\section{Authors}

Shireen Adenwalla, P. Welsch, A. Harken, Jennifer I. Brand, A. Sezer, and Brian W. Robertson 


\title{
Boron carbide/ $\boldsymbol{n}$-silicon carbide heterojunction diodes
}

\author{
S. Adenwalla ${ }^{a}$ \\ Department of Physics and Center for Materials Research and Analysis, University of Nebraska-Lincoln, \\ Lincoln, Nebraska 68588 \\ P. Welsch and A. Harken \\ Department of Mechanical Engineering and Center for Materials Research and Analysis, \\ University of Nebraska-Lincoln, Lincoln, Nebraska 68588 \\ J. I. Brand and A. Sezer \\ Department of Chemical Engineering and Center for Materials Research and Analysis, \\ University of Nebraska-Lincoln, Lincoln, Nebraska 68588 \\ B. W. Robertson \\ Department of Mechanical Engineering and Center for Materials Research and Analysis, \\ University of Nebraska-Lincoln, Lincoln, Nebraska 68588
}

(Received 24 July 2001; accepted for publication 9 October 2001)

The fabrication, initial structural characterization, and diode measurements are reported for a boron carbide/silicon carbide heterojunction diode. Current-voltage curves are obtained for operation at temperatures from 24 to $351{ }^{\circ} \mathrm{C}$. Plasma-enhanced chemical-vapor deposition (PECVD) -deposited undoped boron carbide material is highly crystalline and consists of a variety of polytypes of boron carbide (BC) with crystal sizes as large as $110 \mathrm{~nm}$. Crystal phases are similar to those for PECVD $\mathrm{BC}$ on Si but only partially match known boron and boron-rich BC phases. (C) 2001 American Institute of Physics. [DOI: 10.1063/1.1426257]

Boron carbide has long been valued as a hard, refractory, corrosion-resistant ceramic and investigated as a potential electronic material. ${ }^{1,2}$ If combined with useful semiconducting properties, its mechanical properties make boron carbide attractive for reliable high-temperature devices that function in harsh chemical environments. In the past ten years a semiconducting form of boron carbide (BC) has been successfully grown, by plasma-enhanced chemical-vapor deposition (PECVD), and used in a variety of initial diode and transistor devices. ${ }^{2-4}$ Not all boron-rich BC crystals are semiconducting. The crystal structures of boron-rich boron carbides share the icosahedral building block that is also found in rhombohedral boron. The structural similarities of the boron carbides imply that the energy barriers between these different structures may be small and may lead, under nonequilibrium conditions, to simultaneous formation of a number of different polytypes, as occurs, for example, in silicon carbide. The crystallinity of semiconducting BC films grown by PECVD has been questioned despite the Bragg diffraction peaks in published x-ray diffraction patterns. ${ }^{5}$

Here, we report the promising high-temperature electrical behavior of boron carbide/silicon carbide heterojunction diodes. We also show that the PECVD boron carbide material of these devices contains crystallites that are substantially larger than previously reported.

Boron carbide was grown on $\mathrm{SiC}$ substrates by PECVD using a single precursor, orthocarborane-closo1,2-dicarbadodecaborane $\left(\mathrm{C}_{2} \mathrm{~B}_{10} \mathrm{H}_{12}\right)$. As-received $n$-type nitrogen-doped (111) 6H-SiC wafers (SiCrystal AG, Germany) were cleaved, cleaned, and passivated immediately

\footnotetext{
a) Author to whom correspondence should be addressed; electronic mail: sadenwal@unlserve.unl.edu
}

before insertion into a custom-designed parallel-plate radiofrequency plasma reactor. The substrate heater remained at $350^{\circ} \mathrm{C}$ throughout initial plasma etching (at 200 mTorr and $10 \mathrm{sccm}$ Ar for $30 \mathrm{~min}$ ) and subsequent deposition. Orthocarborane, sublimed at $\sim 50-70{ }^{\circ} \mathrm{C}$, was introduced through a heated manifold by a flow of argon carrier gas. Depositions, using $\sim 25 \mathrm{~W}$ of $13.56 \mathrm{MHz}$ rf power for $15 \mathrm{~min}$ at $\sim 200$ mTorr reactor chamber pressure, were followed by cooling over $1 \mathrm{~h}$ to $250^{\circ} \mathrm{C}$. Coated substrates were cooled to room temperature (in one additional hour) and were stored in vacuum. The BC overlayer was $\sim 2000 \AA$ thick.

Gold contacts, about $1.5 \mathrm{~mm}$ in diameter and at least 100 $\mathrm{nm}$ thick, were sputtered on the BC surface and on the adjacent $\mathrm{SiC}$ surface rather than on the back of the $\mathrm{SiC}$ wafer to minimize the influence of through-wafer $\mathrm{SiC}$ micropipes on the electrical performance. Robust external connections were provided through electrically conductive epoxy on top of the gold contacts. Devices were heated on a hot plate while current and voltage measurements were obtained using Keithley 2400-C SourceMeter and TestPoint software.

The diode current-voltage $(I-V)$ curves from the $\mathrm{Au} /$ $\mathrm{BC} / n$-SiC/Au device were measured at temperatures of 24 , $61,104,141,187,229,288$, and $351^{\circ} \mathrm{C}$. For clarity, only five temperature curves are shown in Fig. 1. Separate measurement of $\mathrm{Au} / \mathrm{SiC} / \mathrm{Au}$ confirmed the Ohmic behavior of the $\mathrm{Au} / \mathrm{SiC}$ junctions at temperatures above $150^{\circ} \mathrm{C}$, in contrast to their well-known Schottky behavior at lower temperatures. Ideality factors, calculated by fitting of the linear portions of logarithmic plots of current as a function of applied bias, fell from $\sim 20$ at room temperature to below 2 at the highest temperature of $351{ }^{\circ} \mathrm{C}$. We attribute this improvement in the ideality factor to the lower resistance of the $\mathrm{BC}$ material at higher temperatures. $\mathrm{BC}$ is a highly resistive material and this large resistance, which is effectively in series 


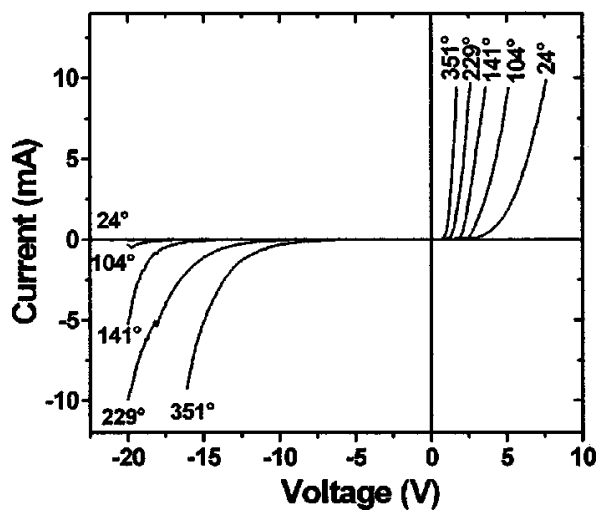

FIG. 1. Current-applied bias $(I-V)$ curves of an $\mathrm{Au} / \mathrm{BC} / n-\mathrm{SiC} / \mathrm{Au}$ device as a function of temperature. Curve labels are temperatures in ${ }^{\circ} \mathrm{C}$.

with the diode, causes this marked deviation from ideality. The SiC device shows lower leakage currents and higher breakdown voltages than the Si device, under similar conditions at all temperatures (see Table I). In general, the reverse saturation current is determined primarily by the number of minority charge carriers in each material with an exponential dependence on the band gap. The band gaps of $\mathrm{Si}$ and $\mathrm{SiC}$ are 1.1 and $3.0 \mathrm{eV}$, respectively, at $300 \mathrm{~K}$; this difference in band gaps of the substrate materials could account for some of the discrepancy.

$\mathrm{X}$-ray diffraction was performed using a Rigaku thetatwo theta diffractometer $(\mathrm{Cu} K \alpha$ radiation) to detect $\mathrm{BC}$ phases present. PECVD $\mathrm{BC}$ on $\mathrm{SiC}$ shows sharp, welldefined peaks [Fig. 2(a)]. Multiple polytypes present in the $\mathrm{SiC}$ produced numerous peaks which were used to correct the observed $\mathrm{BC}$ diffraction angles, a correction that ranges from $-0.2^{\circ}$ at low angles to $-0.3^{\circ}$ at $65^{\circ}$.

The small peak widths indicate that the $\mathrm{BC}$ material has relatively large nanocrystallite dimensions $(\sim 30-110 \mathrm{~nm})$ in contrast to previously reported PECVD BC films. ${ }^{5}$ The peak positions, however, do not correspond to only one known boron carbide crystal type. Elemental rhombohedral boron consists of icosahedra placed at the corners of a rhombohedral unit cell. The addition of carbon leads to the formation of a chain of $\mathrm{B}$ and $\mathrm{C}$ atoms on the body diagonal of the unit cell and/or substitution of some B in the icosahedra by carbon. Small changes in the dimensions and structure of the unit cell as carbon is added to the compound often alter the main diffracting angles by only small fractions of a degree. Distinguishing between the various boron carbide compounds in a micro- or nanocrystalline material using $\mathrm{x}$-ray diffraction is therefore difficult, particularly since boron and carbon differ by 1 in atomic number, and so their x-ray scattering lengths are also quite comparable.

To identify the numerous peaks, we restricted our x-ray

TABLE I. Relevant diode parameters of BC deposited Si and SiC, respectively.

\begin{tabular}{|c|c|c|c|c|}
\hline \multirow[t]{2}{*}{ Temperature } & \multicolumn{2}{|c|}{$\begin{array}{l}\text { Breakdown } \\
\text { voltage }\end{array}$} & \multicolumn{2}{|c|}{$\begin{array}{l}\text { Leakage current } \\
\text { at }-4 \mathrm{~V}\end{array}$} \\
\hline & On $\mathrm{SiC}$ & On Si & On SiC & On Si \\
\hline $24^{\circ} \mathrm{C}$ & $-16.7 \mathrm{~V}$ & $-14.2 \mathrm{~V}$ & $-66.5 \mathrm{nA}$ & $-71.3 \mathrm{nA}$ \\
\hline $340{ }^{\circ} \mathrm{C}$ & & $<-0.1 \mathrm{~V}$ & & $-4.66 \mathrm{~mA}$ \\
\hline $351{ }^{\circ} \mathrm{C}$ & $-4.3 \mathrm{~V}$ & & $-8.02 \mu \mathrm{A}$ & \\
\hline
\end{tabular}
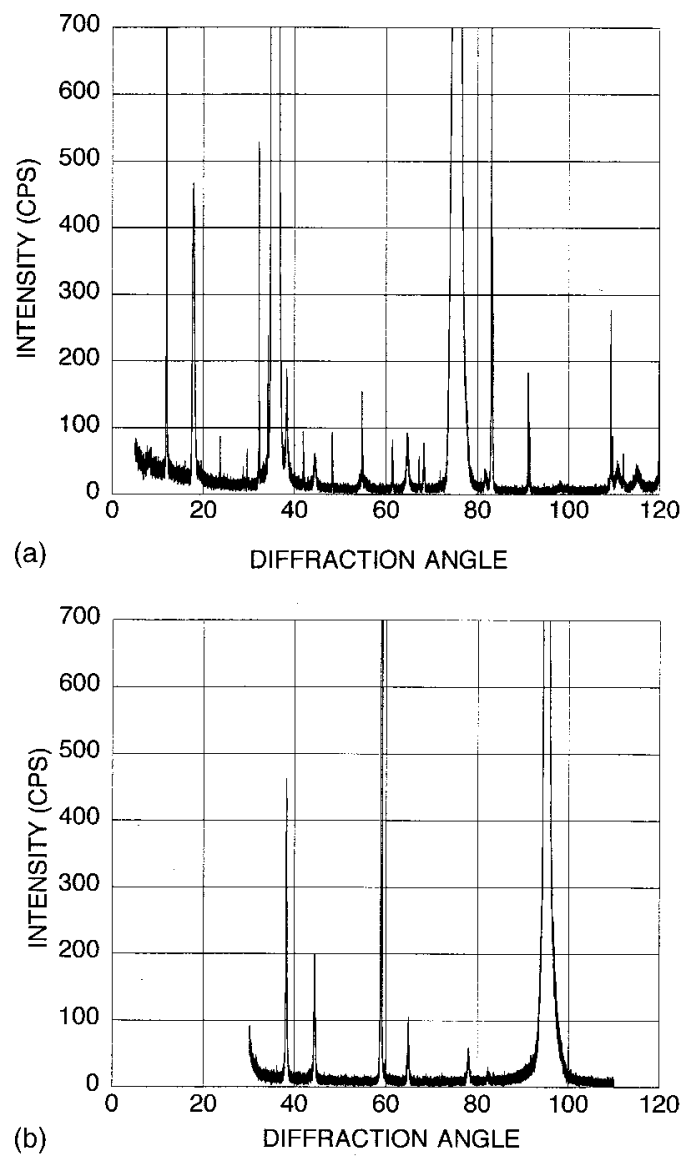

FIG. 2. $\mathrm{Cu} K \alpha$ x-ray diffraction data for BC layers on $\mathrm{SiC}$ and Si substrates: (a) on $\mathrm{SiC}$ and (b) on $\mathrm{Si}$.

diffraction peak search to compounds containing only boron and/or carbon, but not hydrogen. The orthocarborane molecule has a $\mathrm{B}_{10} \mathrm{C}_{2}$ icosahedral core surrounded by 12 hydrogen atoms that are readily removed in the PECVD process. On previous samples, Fourier transform infrared measurements showed little $\mathrm{C}-\mathrm{H}$ or $\mathrm{B}-\mathrm{H}$ bonding and atomic absorption showed less than 5\% hydrogen. There are no x-ray diffraction data reported for $\mathrm{BC}$ compounds containing such low fractions of hydrogen.

The diffraction peaks (corrected for the small shift mentioned above) originating solely from the $\mathrm{BC}$ and not the $\mathrm{SiC}$ substrate are given in Table II, together with the best matches from the powder diffraction file (PDF) data files. The peaks are associated with interplanar spacings that correspond closely with some of those found in tetragonal $\mathrm{B}_{48}\left(\mathrm{~B}_{2} \mathrm{C}_{2}\right)$ (Ref. 6) and the rhombohedral compounds $\mathrm{B}, \mathrm{B}_{12}\left(\mathrm{BC}_{2}\right)$, $\mathrm{B}_{4} \mathrm{C}$, or $\mathrm{B}_{41.1} \mathrm{C}_{4.45}$ but are not consistent with only one compound. For each of these possible phases, the intensities within each group of peaks do not scale according to the intensities for randomly oriented powders given in the International Crystal Diffraction Database Powder Diffraction Files, thus indicating at least some degree of preferred crystalline orientation. The large crystallite sizes, over $100 \mathrm{~nm}$, indicate excellent crystallinity. One of the strongest peaks, at $31.963^{\circ}$, can be assigned to the $\left(\begin{array}{lll}1 & 1 & 0\end{array}\right)$ spacing of a variety of rhombohedral BC compounds, all very close together. The other strong peak, at $82.952^{\circ}$ is closest to the (6 3 2) peak of $\mathrm{B}_{48}\left(\mathrm{~B}_{2} \mathrm{C}_{2}\right)$. Initial high-resolution electron microscopy of as-deposited $\mathrm{BC}$ grown on $\mathrm{Si}$ under slightly 
TABLE II. Bragg $2 \theta$ diffraction angles and interplanar spacings obtained from $\mathrm{Cu} K \alpha$ x-ray diffraction by BC layers on SiC substrates. Also listed are the ICDD Powder Diffraction File (PDF) data for closely matching crystalline phases and associated crystal plane indices. Bold lettering indicates the closest agreement.

\begin{tabular}{|c|c|c|c|c|c|}
\hline $\begin{array}{c}2 \theta \\
\text { (degrees) }\end{array}$ & $\begin{array}{c}\text { Peak } \\
\text { height } \\
\text { (counts) }\end{array}$ & $\begin{array}{l}\text { Size } \\
(\mathrm{nm})\end{array}$ & $\begin{array}{l}\text { Phases (from } \\
\text { ICDD PDF) }\end{array}$ & $\begin{array}{c}\text { PDF } \\
2 \theta \\
\text { (degrees) }\end{array}$ & $\begin{array}{l}\text { PDF phase } \\
\text { index }\end{array}$ \\
\hline 25.077 & 11.5 & 135.6 & Rhombohedral B & 25.11 & $\left(\begin{array}{lll}7 & 2 & 0\end{array}\right)$ \\
\hline 28.49 & 15.6 & 154.6 & $\begin{array}{c}\text { Rhombohedral B } \\
\text { or } \mathrm{B}_{48} \mathrm{~B}_{2} \mathrm{C}_{2}\end{array}$ & $\begin{array}{l}28.218 \\
28.835\end{array}$ & $\begin{array}{l}\left(\begin{array}{ll}-1 & -12\end{array}\right) \\
\left(\begin{array}{llll}2 & 1 & 1\end{array}\right)\end{array}$ \\
\hline 29.358 & 39.2 & 141.6 & & & \\
\hline 31.963 & 495.2 & 147.5 & $\begin{array}{c}\mathrm{B}_{4} \mathrm{C} \\
\text { or } \mathrm{B}_{12}\left(\mathrm{BC}_{2}\right) \\
\mathrm{B}_{6.5} \mathrm{C}\end{array}$ & $\begin{array}{l}31.937 \\
31.946 \\
31.838\end{array}$ & 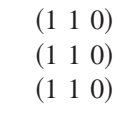 \\
\hline 33.959 & 161 & 177.8 & $\begin{array}{c}\text { B48 B2 C2 } \\
\text { Rhombohedral B }\end{array}$ & $\begin{array}{l}33.982 \\
34.283\end{array}$ & $\begin{array}{c}\left(\begin{array}{lll}2 & 2 & 1\end{array}\right) \\
\left(\begin{array}{lll}-2 & 2 & 1\end{array}\right)\end{array}$ \\
\hline 44.219 & 33.9 & 27.6 & $\begin{array}{c}\mathrm{B}_{48}\left(\mathrm{~B}_{2} \mathrm{C}_{2}\right) \\
\text { Rhombohedral B }\end{array}$ & $\begin{array}{l}44.011 \\
44.527\end{array}$ & $\begin{array}{l}\left(\begin{array}{lll}3 & 3 & 0\end{array}\right) \\
\left(\begin{array}{llll}4 & 4 & 1\end{array}\right)\end{array}$ \\
\hline 64.369 & 60 & 26.1 & $\begin{array}{c}\mathrm{B}_{4} \mathrm{C} \\
\mathrm{B}_{48}\left(\mathrm{~B}_{2} \mathrm{C}_{2}\right)\end{array}$ & $\begin{array}{l}64.374 \\
64.524\end{array}$ & $\begin{array}{l}\left(\begin{array}{lll}0 & 1 & 8\end{array}\right) \\
\left(\begin{array}{llll}3 & 1 & 3\end{array}\right)\end{array}$ \\
\hline 66.889 & 43.8 & 122.2 & $\begin{array}{c}\mathrm{B}_{4} \mathrm{C} \\
\mathrm{B}_{12}\left(\mathrm{BC}_{2}\right)\end{array}$ & $\begin{array}{l}66.765 \\
66.764\end{array}$ & 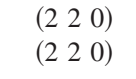 \\
\hline 82.705 & 656 & 134.3 & $\begin{array}{c}\mathrm{B}_{12}\left(\mathrm{BC}_{2}\right) \\
\mathrm{B}_{4} \mathrm{C}\end{array}$ & $\begin{array}{l}82.821 \\
82.544\end{array}$ & $\begin{array}{l}\left(\begin{array}{lll}6 & 3 & 2\end{array}\right) \\
\left(\begin{array}{lll}1 & 2 & 8\end{array}\right)\end{array}$ \\
\hline 82.952 & 304 & 136.2 & $\mathrm{~B}_{48}\left(\mathrm{~B}_{2} \mathrm{C}_{2}\right)$ & 83.45 & $\left(\begin{array}{lll}6 & 3 & 2\end{array}\right)$ \\
\hline
\end{tabular}

different conditions has revealed 3-nm-sized crystals. Lattice fringes in these crystals correspond to interplanar spacings $0.21 \pm 0.01,0.24 \pm 0.01$, and $0.32 \pm 0.01 \mathrm{~nm},{ }^{7}$ which are close to the present $\mathrm{x}$-ray diffraction results.

Figure 2(b) shows the data for samples grown by us on $\mathrm{Si}$ under similar conditions to the growth on $\mathrm{SiC}$. The peak widths correspond to crystals that are somewhat smaller $(\sim 10-100 \mathrm{~nm})$ than those grown on SiC. By comparison of the X-ray diffraction pattern for growth on SiC [Fig. 2(a)] with those for growth on Si [Fig. 2(b)], it is clear that the choice of substrate influences the growth, both in the proportion of phases present and in the crystallinity Performing a similar analysis on the $\mathrm{BC} / \mathrm{Si} \mathrm{X}$-ray peaks, the predominant phases present are tetragonal $\mathrm{B}_{48}\left(\mathrm{~B}_{2} \mathrm{C}_{2}\right)$ and rhombohedral $\mathrm{B}$.

As pointed out earlier, the subtle differences in structure among the family of BC compounds makes a unique identification difficult. Two facts remain clear-we have more than one phase present and the material is extremely crystalline.

In summary, undoped $\mathrm{BC} / n-\mathrm{SiC}$ devices show good semiconductor diode behavior, from room temperature to $351{ }^{\circ} \mathrm{C}$, which is superior to the $\mathrm{BC} / n$-Si behavior previously reported. ${ }^{3}$ The superior diode performance of the device on $\mathrm{SiC}$ may relate to its improved crystallinity as well as to the larger band gap of the substrate. Nanocrystalline material deposited under present PECVD reactor conditions exhibits narrow $\mathrm{x}$-ray diffraction peaks at angles that correspond closely to several boron and boron-carbon phases that we have identified but not fully to any one of these phases.

The preliminary electrical assessment indicates that high-temperature operation may be successful. It is now important to identify the phase that contributes the most desir- able semiconducting behavior in order that this promising semiconducting system can be better understood and used in high temperature and other applications.

This work was supported by the Air Force Office of Scientific Research, the National Science Foundation, and the Nebraska Research Initiative. X-ray diffraction and electron microscopy used the central facilities of the Center for Materials Research and Analysis at the University of Nebraska-Lincoln. One of the authors (B.W.R.) is grateful to Professor John Titchmarsh and the Department of Materials at the University of Oxford, England, for the invitation to conduct research on sabbatical in Oxford and for the provision of access to electron microscopy facilities there.

${ }^{1}$ H. E. Robson, Ph.D. thesis, University of Kansas, Lawrence, Kansas (1959); H. Werheit, NATO ASI Ser., Ser. 3 68, 65 (1999).

${ }^{2}$ S. Lee, J. Mazurowski, G. Ramseyer, and P. A. Dowben, J. Appl. Phys. 72, 4925 (1992).

${ }^{3}$ S. Lee and P. A. Dowben, Appl. Phys. A: Solids Surf. 58, 223 (1994).

${ }^{4}$ B. W. Robertson and P. A. Dowben, in Proceedings of the 2nd European High Temperature Electronics Conference (HITEN 97) (AEA Technology, Didcot, United Kingdom, 1998), p. 219.

${ }^{5}$ S.-d. Hwang, P. A. Dowben, A. Cheeseman, J. T. Spencer, and D. N. McIlroy, Mater. Res. Soc. Symp. Proc. 452, 1031 (1997).

${ }^{6}$ G. Will and K. Ploog, Nature (London) 251, 406 (1974). The unit cell in $\mathrm{B}_{48}\left(\mathrm{~B}_{2} \mathrm{C}_{2}\right)$ consists of four boron icosahedra in a tetragonal arrangement, like that in tetragonal boron, but with the two carbon atoms and the two remaining boron atoms occupying intericosahedral sites.

${ }^{7}$ M. Bai, C. Davenport, and B. W. Robertson (unpublished data). 